\title{
Supramolecular assembly of linear trinickel complexes incorporating metalloporphyrins: a novel one-dimensional polymer and oligomer
}

\author{
Ting-Bin Tsao, Gene-Hsiang Lee, Chen-Yu Yeh and Shie-Ming Peng* \\ Department of Chemistry, National Taiwan University, Taipei, Taiwan, ROC. \\ E-mail: smpeng@mail.ch.ntu.edu.tw
}

Received 12th December 2002, Accepted 26th February 2003

First published as an Advance Article on the web 13th March 2003

\begin{abstract}
One-dimensional polymeric or oligomeric chains, in which various linear trinickel complexes linked to the axial sites of metalloporphyrins by the combination of self-assembly and coordination chemistry, have been constructed. A carboxylate group of carboxylpyridine was attached to the end of linear trinickel complexes to produce the linear building blocks, $\mathrm{Ni}_{3}(\mathrm{dpa})_{4} \mathrm{X}_{2}\left[\mathrm{X}=4-\mathrm{PyCOO}^{-}(\mathbf{1})\right.$ or 3-PyCOO$\left.{ }^{-}(2)\right]$, which was then reacted with metalloporphyrins to form stable polymers or oligomers. The new self-assembled oligomeric chain, $\left[\mathrm{Ni}_{3}(\mathrm{dpa})_{4}(4-\mathrm{PyCOO})_{2}\right][\mathrm{ZnTPP}]_{2}(\mathbf{3})$, and two novel self-assembled one-dimensional polymeric chains, $\left\{\left[\mathrm{Ni}_{3}(\mathrm{dpa})_{4}(4-\mathrm{PyCOO})_{2}\right][\mathrm{MnTPP}]\right\}_{n}\left(\mathrm{ClO}_{4}\right)_{n}(\mathbf{4})$, and $\left\{\left[\mathrm{Ni}_{3}(\mathrm{dpa})_{4}(3-\mathrm{PyCOO})_{2}\right][\mathrm{MnTPP}]\right\}_{n}\left(\mathrm{ClO}_{4}\right)_{n}(\mathbf{5})$, [dpa ${ }^{-}=\mathrm{di}(\alpha-$ pyridyl $)$ amido anion; TPP $=$ meso-tetraphenylporphyrinato dianion], have been synthesized and their structures were determined by X-ray diffraction. The UV/vis spectra indicate the absence of any noticeable interactions between the linear trinickel units and metalloporphyrins in these chains. The magnetic susceptibility measurements in the solid state show that both polymers $\mathbf{4}$ and $\mathbf{5}$ have a very weak ferromagnetic interaction.
\end{abstract}

\section{Introduction}

Various linear multinuclear metal string complexes with oligo$\alpha$-pyridylamine as the supporting ligands have attracted much attention because of their versatile chemical and physical properties and the potential application as molecular metal wires, since the first reports of the trinuclear copper and nickel complexes bridged by di- $\alpha$-pyridylamido ligand in $1990-1991 .^{1,2}$ Polymers and oligomers containing linear multinuclear metal string complexes in the backbone may display novel conductive, optical, and magnetic properties. ${ }^{3}$ A number of bimetallic carboxylates, linked by bidentate axial ligands, leading to onedimensional polymeric species have been studied..$^{4-8}$ Especially, efforts to synthesized magnetic chain compounds have been done. ${ }^{8}$ In our multinuclear metal string complexes, it is only for linear trinickel complex that the one-dimensional polymeric form has been reported. ${ }^{9}$ The optical, electronic, and photophysical properties of porphyrins have made these molecules desirable targets for incorporation into supramolecular systems and polymers due to their central importance for variety of potential applications such as sensors, ${ }^{10}$ magnetic materials, ${ }^{11}$ and catalyst. ${ }^{12}$ A number of one-dimensional polymeric chains have also been generated by linear bidentate units such as imidazole and 4,4'-bipyridine through the coordination of ligands to metal centers of metalloporphyrins. ${ }^{13-19}$ To the best of our knowledge, however, no studies have been attempted to use both linear metal string complexes and metalloporphyrins as building blocks for the construction of supramolecules or polymers. Therefore, we set off to construct one-dimensional polymeric or oligomeric chains containing both linear metal string complexes and metalloporphyrins. As shown in Scheme 1, our approach towards supramolecular assembly uses a $\left[\mathrm{Ni}_{3}(\mathrm{dpa})_{4}(\mathrm{PyCOO})_{2}\right]$ building block and a metalloporphyrin such as zinc tetraphenylporphyrin ( $\left.\mathrm{Zn}^{\mathrm{II}} \mathrm{TPP}\right)$ and manganese tetraphenylporphyrin $\left(\mathrm{Mn}^{\mathrm{III}} \mathrm{TPP}\right)^{+}$as building blocks.

In this report, we present the structure and physical properties of the trimeric oligomer, $\left[\mathrm{Ni}_{3}(\mathrm{dpa})_{4}(4-\mathrm{PyCOO})_{2}\right]$ $[\mathrm{ZnTPP}]_{2}(3)$, and two one-dimensional polymeric chains, $\left\{\left[\mathrm{Ni}_{3}(\mathrm{dpa})_{4}(4-\mathrm{PyCOO})_{2}\right][\mathrm{MnTPP}]\right\}_{n}\left(\mathrm{ClO}_{4}\right)_{n}(4)$, and $\left\{\left[\mathrm{Ni}_{3}(\mathrm{dpa})_{4}{ }^{-}\right.\right.$ $\left.\left.(3-\mathrm{PyCOO})_{2}\right][\mathrm{MnTPP}]\right\}_{n}\left(\mathrm{ClO}_{4}\right)_{n}(\mathbf{5})$.

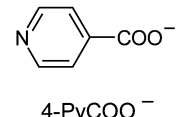

$4-\mathrm{PyCOO}^{-}$

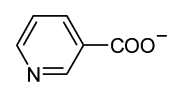

3-PyCOO

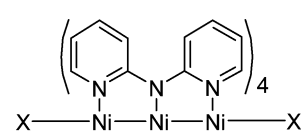

$\left[\mathrm{Ni}_{3}(\mathrm{dpa})_{4} \mathrm{X}_{2}\right]$

1. $\mathrm{X}=4-\mathrm{PyCOO}^{-}$

2. $\mathrm{X}=3-\mathrm{PyCOO}^{-}$

Scheme 1

\section{Results and discussion}

\section{Synthesis and characterization}

The synthetic procedures for complexes $\mathbf{1}, \mathbf{2}, \mathbf{3}, \mathbf{4}$, and 5 are summarized in Scheme 2. The starting material, $\left[\mathrm{Ni}_{3}(\mathrm{dpa})_{4} \mathrm{Cl}_{2}\right]$, was converted to $\left[\mathrm{Ni}_{3}(\mathrm{dpa})_{4}\left(\mathrm{SO}_{3} \mathrm{CF}_{3}\right)_{2}\right]$ by the use of $\mathrm{AgSO}_{3}$ $\mathrm{CF}_{3}$. The building block $\left[\mathrm{Ni}_{3}(\mathrm{dpa})_{4}(\mathrm{PyCOO})_{2}\right]$ was synthesized, in moderate yield and high purity, by reacting $\left[\mathrm{Ni}_{3}(\mathrm{dpa})_{4^{-}}\right.$ $\left.\left(\mathrm{SO}_{3} \mathrm{CF}_{3}\right)_{2}\right]$ with two equivalents of $\mathrm{PyCOO}^{-}\left(\mathrm{CH}_{3}\right)_{4} \mathrm{~N}^{+}$, which was prepared in situ from the corresponding pyridylcarboxylic acid and $\left(\mathrm{CH}_{3}\right)_{4} \mathrm{NOH}$. Porphyrin building blocks $\mathrm{ZnTPP}$ and $[\mathrm{MnTPP}]\left(\mathrm{ClO}_{4}\right)$ were synthesized by standard procedures. ${ }^{20,21}$ Treatment of complex 1 with ZnTPP in dry $\mathrm{CH}_{2} \mathrm{Cl}_{2}$ gives bright purple crystals of the trimeric oligomer 3 . Two novel onedimensional polymers $\mathbf{4}$ and $\mathbf{5}$ with a backbone consisting of $\left[\mathrm{Ni}_{3}(\mathrm{dpa})_{4}(\mathrm{PyCOO})_{2}\right]$ and $[\mathrm{MnTPP}]^{+}$have been prepared by treating the $\left[\mathrm{Ni}_{3}(\mathrm{dpa})_{4}(\mathrm{PyCOO})_{2}\right]$ and $[\mathrm{MnTPP}]\left(\mathrm{ClO}_{4}\right)$ in $1: 1$ molar ratio.

The IR active $\mathrm{C}=\mathrm{O}$ stretching vibration gives rise to band at $1630 \mathrm{~cm}^{-1}$ and $\mathrm{C}-\mathrm{C}$ vibrational modes of the pyridine ring are shown in the range of $1200-1600 \mathrm{~cm}^{-1}$ for complexes $\mathbf{1}-\mathbf{5}$. All these complexes are air stable and soluble in most organic solvents, e.g. $\mathrm{CH}_{2} \mathrm{Cl}_{2}, \mathrm{CHCl}_{3}, \mathrm{CH}_{3} \mathrm{CN}, \mathrm{CH}_{3} \mathrm{OH}$, and THF etc.

Attempts to prepare one-dimensional polymeric chain with $\left[\mathrm{Ni}_{3}(\mathrm{dpa})_{4}(\mathrm{PyCOO})_{2}\right]$ and $\mathrm{ZnTPP}$ have not yet been successful. It has been considerably more difficult to construct extended coordination polymers with ZnTPP building blocks, due to the low affinity of the zinc ion for an octahedral ligation environment. 
Table 1 Crystal data and structure refinement for complexes 1-5

\begin{tabular}{|c|c|c|c|c|c|}
\hline & 1 & 2 & 3. $\mathrm{CH}_{2} \mathrm{Cl}_{2}$ & $4 \cdot 3 \mathrm{CH}_{3} \mathrm{OH}$ & $\mathbf{5} \cdot 3 / 2\left(\mathrm{C}_{2} \mathrm{H}_{5}\right)_{2} \mathrm{O} \cdot \mathrm{CHCl}_{3}$ \\
\hline Formula & $\mathrm{C}_{52} \mathrm{H}_{40} \mathrm{~N}_{14} \mathrm{Ni}_{3} \mathrm{O}_{4}$ & $\mathrm{C}_{52} \mathrm{H}_{40} \mathrm{~N}_{14} \mathrm{Ni}_{3} \mathrm{O}_{4}$ & $\mathrm{C}_{141} \mathrm{H}_{98} \mathrm{Cl}_{2} \mathrm{~N}_{22} \mathrm{Ni}_{3} \mathrm{O}_{4} \mathrm{Zn}_{2}$ & $\mathrm{C}_{99} \mathrm{H}_{80} \mathrm{ClMnN}_{18} \mathrm{Ni}_{3} \mathrm{O}_{11}$ & $\mathrm{C}_{103} \mathrm{H}_{84} \mathrm{Cl}_{4} \mathrm{MnN}_{18} \mathrm{Ni}_{3} \mathrm{O}_{9.5}$ \\
\hline Formula weight & 1101.11 & 1101.11 & 2542.18 & 1964.33 & 2098.75 \\
\hline Temperature/K & $150(1)$ & $150(1)$ & $150(1)$ & $150(1)$ & $150(1)$ \\
\hline Crystal system & Monoclinic & Monoclinic & Triclinic & Monoclinic & Monoclinic \\
\hline Space group & $P 2_{1} / n$ & $P 2_{1} / n$ & $P \overline{1}$ & $C 2 / c$ & $P 2_{1} / c$ \\
\hline al⿵ & $16.5862(1)$ & $16.3803(1)$ & $13.2756(1)$ & $35.1566(2)$ & $21.3217(2)$ \\
\hline b/Å & $16.1383(1)$ & $16.0704(1)$ & $17.4339(1)$ & $18.0237(1)$ & $24.9858(2)$ \\
\hline$c / \AA$ & $18.2700(1)$ & $18.7595(2)$ & $26.7913(2)$ & $16.1465(1)$ & $18.0492(2)$ \\
\hline$a /^{\circ}$ & 90 & 90 & $77.0290(3)$ & 90 & 90 \\
\hline$\beta 1^{\circ}$ & $103.0389(4)$ & $104.4908(5)$ & $85.9760(3)$ & $114.9287(3)$ & $99.3679(5)$ \\
\hline$\gamma /{ }^{\circ}$ & 90 & 90 & $88.9666(3)$ & 90 & 90 \\
\hline$V / \AA^{3}, Z$ & $4764.30(5), 4$ & $4781.12(7), 4$ & $6027.59(7), 2$ & $9278.04(9), 4$ & $9487.29(16), 4$ \\
\hline Absorption coefficient $/ \mathrm{mm}^{-1}$ & 1.237 & 1.233 & 0.963 & 1.406 & 0.900 \\
\hline Reflections collected & 33878 & 31983 & 102583 & 36342 & 58673 \\
\hline Independent reflections $\left(R_{\text {int }}\right)$ & $10901(0.0460)$ & $10965(0.0381)$ & $27641(0.0661)$ & $10662(0.0491)$ & $21661(0.0489)$ \\
\hline$R_{F}, R_{w F}^{2}(\text { all data })^{a}$ & $0.0744,0.1281$ & $0.0677,0.1357$ & $0.1123,0.1677$ & $0.0929,0.1975$ & $0.0929,0.1606$ \\
\hline$R_{F}, R_{w F}^{2}(I>2 \sigma(I))^{a}$ & $0.0446,0.1030$ & $0.0469,0.1182$ & $0.0590,0.1347$ & $0.0611,0.1725$ & $0.0576,0.1403$ \\
\hline${ }^{a} R_{F}=\Sigma\left|F_{\mathrm{o}}-F_{\mathrm{c}}\right| / \Sigma\left|F_{\mathrm{o}}\right| ; R_{w F}{ }^{2}=$ & $\left.F_{\mathrm{o}}{ }^{2}-\left.F_{\mathrm{c}}{ }^{2}\right|^{2} / \Sigma w F_{\mathrm{o}}^{4}\right]^{1}$ & & & & \\
\hline
\end{tabular}

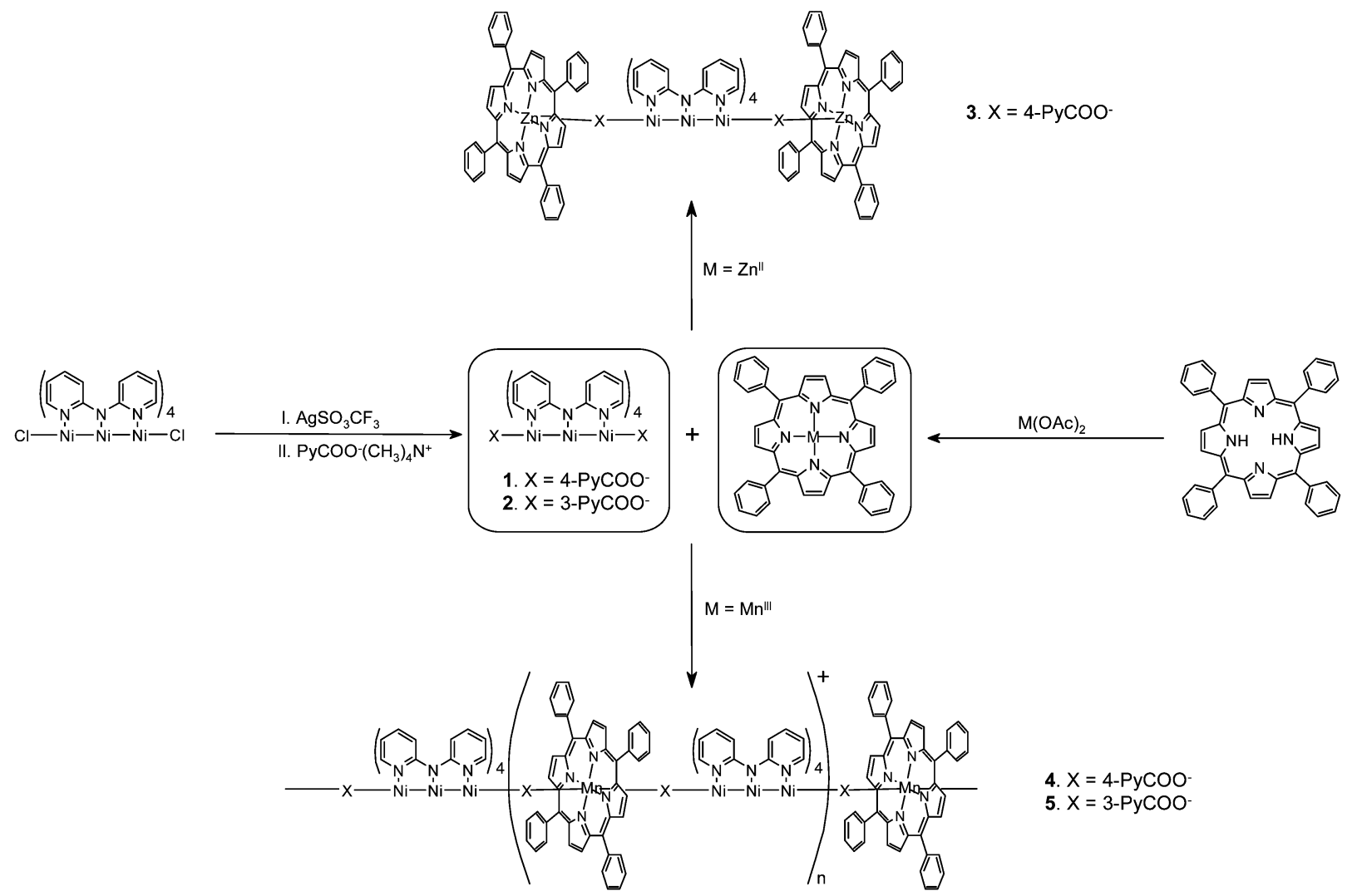

Scheme 2 Synthetic routes for building blocks 1 and 2 and complexes 3-5.

\section{Crystal structures}

\section{Building blocks 1 and 2}

The details of data collection and refinement for complexes 1 and $\mathbf{2}$ are summarized in Table 1. The selected bond distances are listed in Table 2. Both complexes crystallize in the space group $P 2_{1} / n$ with the complexes located at the general positions. As is in most case of $\left[\mathrm{Ni}_{3}(\mathrm{dpa})_{4} \mathrm{X}_{2}\right],{ }^{4}$ where $\mathrm{X}$ is the axial ligand, the $\left[\mathrm{Ni}_{3}(\mathrm{dpa})_{4}\right]^{2+}$ unit in these complexes is helical with the linear trinickel chain being wrapped by four all-syn type dpa ligands, and exhibits approxiate $D_{4}$ symmetry. The crystal structure of complexes $\mathbf{1}$ and $\mathbf{2}$ are shown in Fig. 1 and 2, respectively. The crystal structure of complexes $\mathbf{1}$ and $\mathbf{2}$ have much in common except that the axial ligands are different. The central $\mathrm{Ni}^{\mathrm{II}}$ ions of both complexes $\mathbf{1}$ and $\mathbf{2}$ are square planar with four short $\mathrm{Ni}-\mathrm{N}_{\text {amido }}$ distances in the range of $1.880-1.898 \AA$, which

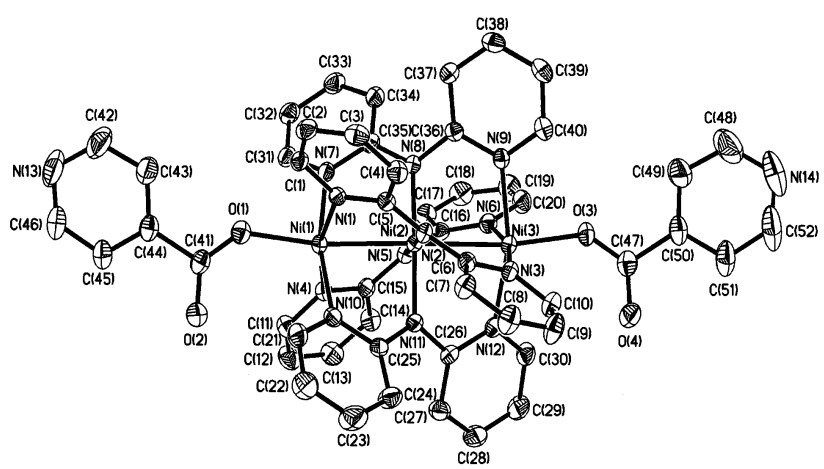

Fig. 1 ORTEP view of crystal structure of 1. Thermal ellipsoids are drawn at the $50 \%$ probability level. Hydrogen atoms are omitted for clarity. 
Table 2 Selected bond distances $(\AA)$ for complexes $\mathbf{1}$ and $\mathbf{2}$

\begin{tabular}{lll}
\hline & 1 & \multicolumn{1}{l}{} \\
\hline & & \\
\hline $\mathrm{Ni}(1)-\mathrm{Ni}(2)$ & $2.4176(4)$ & $2.4214(5)$ \\
$\mathrm{Ni}(2)-\mathrm{Ni}(3)$ & $2.4297(5)$ & $2.4136(5)$ \\
$\mathrm{Ni}(1)-\mathrm{O}(1)$ & $2.013(2)$ & $2.043(2)$ \\
$\mathrm{Ni}(3)-\mathrm{O}(3)$ & $2.018(2)$ & $1.991(2)$ \\
$\mathrm{Ni}(1)-\mathrm{N}_{\text {av. }}$ & $2.080(2)$ & $2.088(2)$ \\
$\mathrm{Ni}(2)-\mathrm{N}_{\text {av. }}$ & $1.889(2)$ & $1.890(2)$ \\
$\mathrm{Ni}(3)-\mathrm{N}_{\text {av. }}$ & $2.094(2)$ & $2.090(2)$ \\
\hline
\end{tabular}

Table 3 Selected bond distances $(\AA)$ and angles $\left({ }^{\circ}\right)$ for complex 3

\begin{tabular}{llll}
\hline $\mathrm{Ni}(1)-\mathrm{Ni}(2)$ & $2.4212(6)$ & $\mathrm{Zn}(1)-\mathrm{N}(13)$ & $2.220(3)$ \\
$\mathrm{Ni}(2)-\mathrm{Ni}(3)$ & $2.4067(6)$ & $\mathrm{Zn}(2)-\mathrm{N}(14)$ & $2.179(3)$ \\
$\mathrm{Ni}(1)-\mathrm{O}(1)$ & $2.006(2)$ & $\mathrm{Zn}(1)-\mathrm{N}_{\text {av. }}$ & $2.070(3)$ \\
$\mathrm{Ni}(3)-\mathrm{O}(3)$ & $1.977(2)$ & $\mathrm{Zn}(2)-\mathrm{N}_{\text {av. }}$ & $2.065(3)$ \\
$\mathrm{Ni}(1)-\mathrm{N}_{\text {av. }}$ & $2.092(3)$ & $\mathrm{Ni}(3)-\mathrm{N}_{\text {av. }}$ & $2.079(3)$ \\
$\mathrm{Ni}(2)-\mathrm{N}_{\text {av. }}$ & $1.892(3)$ & & \\
& & & \\
$\mathrm{Ni}(1)-\mathrm{Ni}(2)-\mathrm{Ni}(3)$ & $179.24(2)$ & $\mathrm{N}(15)-\mathrm{Zn}(1)-\mathrm{N}(17)$ & $162.38(11)$ \\
$\mathrm{O}(1)-\mathrm{Ni}(1)-\mathrm{Ni}(2)$ & $169.06(8)$ & $\mathrm{N}(16)-\mathrm{Zn}(1)-\mathrm{N}(18)$ & $162.09(11)$ \\
$\mathrm{Ni}(2)-\mathrm{Ni}(3)-\mathrm{O}(3)$ & $172.33(7)$ & $\mathrm{N}(19)-\mathrm{Zn}(2)-\mathrm{N}(21)$ & $166.50(11)$ \\
& & $\mathrm{N}(20)-\mathrm{Zn}(2)-\mathrm{N}(22)$ & $163.16(11)$ \\
\hline
\end{tabular}

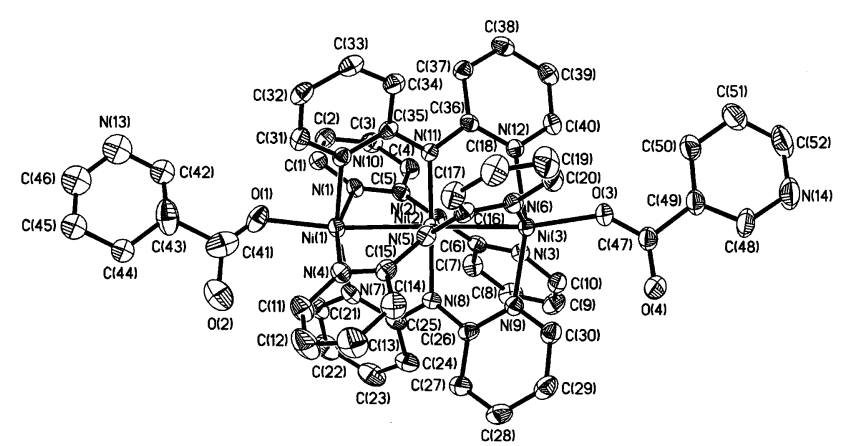

Fig. 2 ORTEP view of crystal structure of 2. Thermal ellipsoids are drawn at the $50 \%$ probability level. Hydrogen atoms are omitted for clarity.

are consistent with a low-spin $(S=0)$ square planer $\mathrm{Ni}^{\mathrm{II}}$ configuration system. Two terminal $\mathrm{Ni}^{\mathrm{II}}$ ions are in a square pyramidal environment with average $\mathrm{Ni}-\mathrm{N}_{\text {pyridine }}$ distances in the range of 2.080-2.094(2) $\AA^{2,9,22-24}$ The averaged $\mathrm{Ni}-\mathrm{Ni}$ distances in 1 and 2 are 2.424(5) and 2.418(5) $\AA$, respectively.

\section{Trimeric oligomer 3}

A summary of crystal data for complex $\mathbf{3}$ is listed in Table 1. The selected bond distances and angles are listed in Table 3. Complex 3 crystallizes in space group $P \overline{1}$ with the molecular complex locates at general position.

As shown in Fig. 3 (top), the oligomeric moieties maintain a "wheel-and-axle" shape, the bridging bidentate unit, $\left[\mathrm{Ni}_{3}-\right.$ $\left.(\mathrm{dpa})_{4}(\mathrm{PyCOO})_{2}\right]$, being aligned to the axial sites of the metalloporphyrin units. The trinickel unit is again essentially symmetrical with $\mathrm{Ni}-\mathrm{Ni}$ distances $2.4216(6)$ and 2.4067(6) $\AA$ The Ni-N distances are 2.092(3), 1.892(3), and 2.079(3) $\AA$ for $\mathrm{Ni}(1), \mathrm{Ni}(2)$, and $\mathrm{Ni}(3)$, respectively. The zinc ions deviate by $0.27 \AA$ from the plane of the four pyrrole nitrogens towards the axially coordinated pyridyl group. All bond distances in ZnTPP units are in the normal range. The crystal packing of complex 3 is shown in Fig. 3 (bottom). The complex 3 units interlock with one another, the porphyrin components forming a characteristic corrugated stacked arrangement throughout the crysta lattice. The intrachain $\mathrm{Zn} \cdots \mathrm{Zn}$ separation is $22.048 \AA$. Formation of similar supramolecular trimer consisting of one bridging ligand and two ZnTPP moieties has been reported earlier. ${ }^{17-19}$ The $\mathrm{Zn}^{\text {II }}$ ion has a strong affinity for a five-coordin-
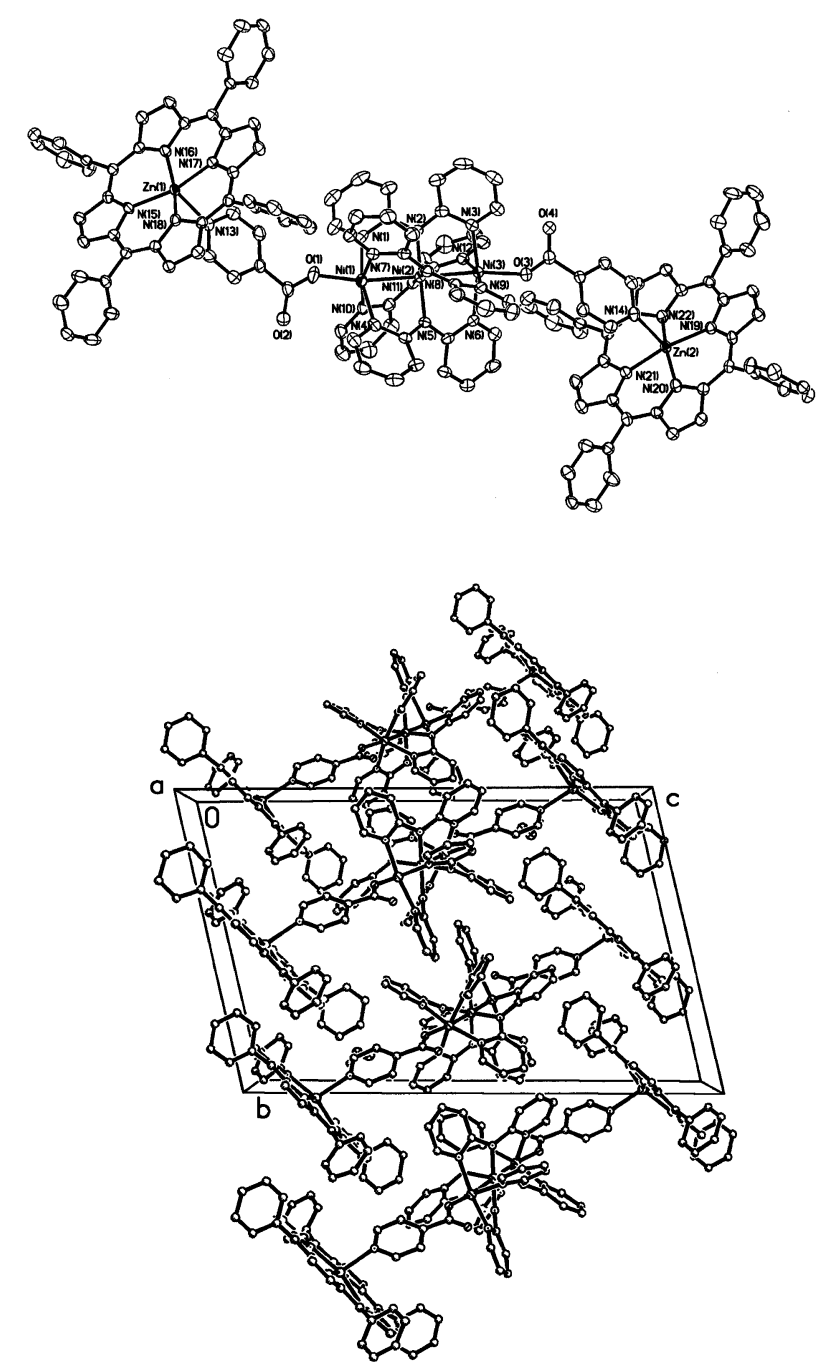

Fig. 3 ORTEP view of crystal structure (top) and packing (bottom) of 3. Thermal ellipsoids (top) are drawn at the $50 \%$ probability level. Hydrogen atoms are omitted for clarity.

ate environment, which favors axial ligation of only one ligand to the ZnTPP moiety. Only a few examples of six-coordinate complexes of various zinc porphyrin derivatives with amine axial ligand have been characterized. ${ }^{19}$

\section{Coordination polymers 4 and 5}

Supramolecular coordination polymers of metalloporphyrins induced by axial coordination of bridging units to the core ions of the porphhyrin species are much less abundant in the literature than their oligomeric counterparts. This can be attributed mainly to an entropic effect. The paramagnetic $\mathrm{Mn}^{\mathrm{III}}$ ion tends to adopt a six-coordinate structure. This should facilitate the formation of coordination polymers with suitable multidentate ligands which might have significant potential as molecular magnetic materials. Two novel one-dimensional coordination polymers $\mathbf{4}$ and $\mathbf{5}$ have been synthesized and their structures were determined by X-ray diffraction as shown in Fig. 4 and 5 , respectively. Summaries of crystal data for complexes $\mathbf{4}$ and $\mathbf{5}$ are listed in Table 1. The selected bond distances and angles are listed in Table 4 . Complex 4 crystallizes in $C 2 / c$ space group with $\mathrm{Mn}(1)$ locates at -1 and $\mathrm{N}(5)-\mathrm{Ni}(2)-\mathrm{N}(7)$ is 2 -fold axis. Complex 5 crystallizes in $P 2_{1} / c$ space group with molecules residing in general positions.

The linear polymeric strands consist of alternating $\left[\mathrm{Ni}_{3}-\right.$ $\left.(\mathrm{dpa})_{4}(\mathrm{PyCOO})_{2}\right]$ and $[\mathrm{MnTPP}]^{+}$building blocks. The $\left[\mathrm{Ni}_{3}(\mathrm{dpa})_{4}\right]^{2+}$ unit in complexes $\mathbf{4}$ and $\mathbf{5}$ exhibit approxiate $D_{4}$ symmetry. The porphyrin rings of both complexes $\mathbf{4}$ and $\mathbf{5}$ are 
Table 4 Selected bond distances $(\AA)$ and angles $\left({ }^{\circ}\right)$ for complexes 4 and 5

\begin{tabular}{|c|c|c|c|}
\hline \multicolumn{4}{|l|}{ Complex 4} \\
\hline $\mathrm{Ni}(1)-\mathrm{Ni}(2)$ & $2.4088(4)$ & $\mathrm{Ni}(1)-\mathrm{O}(1)$ & $2.025(3)$ \\
\hline $\mathrm{Ni}(1)-\mathrm{N}_{\mathrm{av}}$ & $2.092(3)$ & $\mathrm{Ni}(2)-\mathrm{N}_{\mathrm{av}}$ & $1.883(3)$ \\
\hline $\mathrm{Mn}(1)-\mathrm{N}(8)$ & $2.358(3)$ & $\mathrm{Mn}(1)-\mathrm{N}_{\mathrm{av}}$ & $2.011(3)$ \\
\hline $\mathrm{Ni}(1)-\mathrm{Ni}(2)-\mathrm{Ni}(1 \mathrm{~A})$ & $179.92(4)$ & $\mathrm{Ni}(2)-\mathrm{Ni}(1)-\mathrm{O}(1)$ & $174.01(8)$ \\
\hline $\mathrm{N}(9)-\mathrm{Mn}(1)-\mathrm{N}(9 \mathrm{~A})$ & $180.00(9)$ & $\mathrm{N}(10)-\mathrm{Mn}(1)-\mathrm{N}(10 \mathrm{~A})$ & $180.00(1)$ \\
\hline \multicolumn{4}{|l|}{ Complex 5} \\
\hline $\mathrm{Ni}(1)-\mathrm{Ni}(2)$ & $2.4156(5)$ & $\mathrm{Ni}(2)-\mathrm{Ni}(3)$ & $2.4206(5)$ \\
\hline $\mathrm{Ni}(1)-\mathrm{O}(1)$ & $2.001(2)$ & $\mathrm{Ni}(3)-\mathrm{O}(3)$ & $1.985(2)$ \\
\hline $\mathrm{Ni}(1)-\mathrm{N}_{\mathrm{av}}$ & $2.086(3)$ & $\mathrm{Ni}(2)-\mathrm{N}_{\mathrm{av}}$ & $1.890(3)$ \\
\hline $\mathrm{Ni}(3)-\mathrm{N}_{\mathrm{av}}$ & $2.089(3)$ & $\mathrm{Mn}(1)-\mathrm{N}(17)$ & $2.346(3)$ \\
\hline $\operatorname{Mn}(1)-\mathrm{N}(18)$ & $2.339(3)$ & $\mathrm{Mn}(1)-\mathrm{N}_{\mathrm{av}}$ & $2.013(3)$ \\
\hline $\mathrm{Ni}(1)-\mathrm{Ni}(2)-\mathrm{Ni}(3)$ & $177.96(2)$ & $\mathrm{N}(13)-\mathrm{Mn}(1)-\mathrm{N}(15)$ & $179.77(11)$ \\
\hline $\mathrm{Ni}(2)-\mathrm{Ni}(3)-\mathrm{O}(3)$ & $172.53(7)$ & $\mathrm{N}(14)-\mathrm{Mn}(1)-\mathrm{N}(16)$ & $179.74(11)$ \\
\hline $\mathrm{O}(1)-\mathrm{Ni}(1)-\mathrm{Ni}(2)$ & $174.52(7)$ & & \\
\hline
\end{tabular}
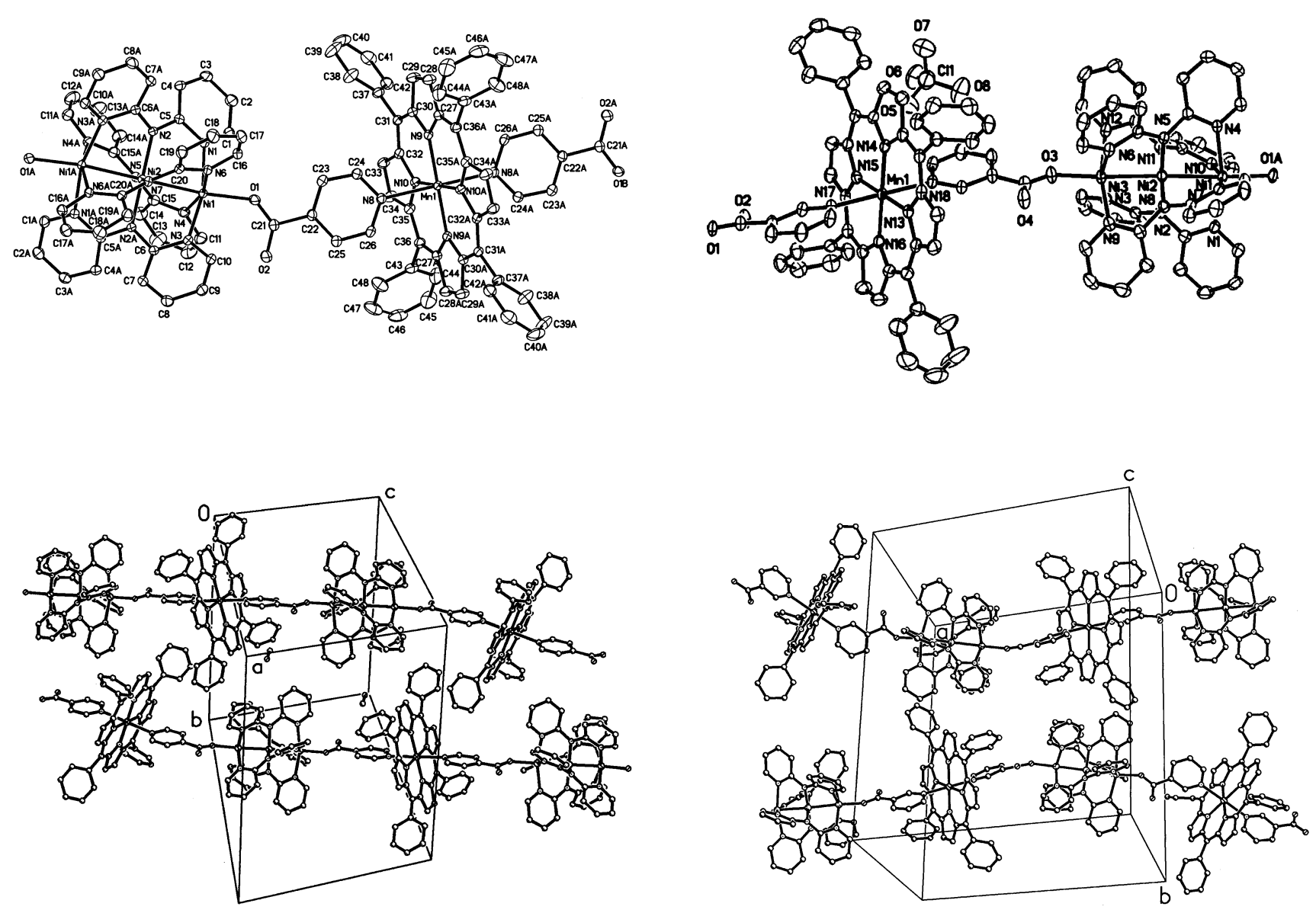

Fig. 4 ORTEP view of crystal structure (top) and packing (bottom) of 4. Thermal ellipsoids (top) are drawn at the $30 \%$ probability level. Hydrogen atoms are omitted for clarity.

perfectly planar. The pyridyl $\mathrm{N}$ atoms coordinate to both axial positions of the $\mathrm{Mn}^{\mathrm{III}}$ ions with distances being 2.358(3) and 2.358(3) Å for 4, and 2.346(3) and 2.339(3) Å for 5, respectively. As shown in Fig. 4 and 5 (bottom), crystal packing of both complexes $\mathbf{4}$ and $\mathbf{5}$ reveal that infinite polymeric chains are approximately parallel to each other. The intrachain Mn … Mn separations are 23.17 and $21.76 \AA$ for $\mathbf{4}$ and $\mathbf{5}$, respectively. To determine the spin state of $\mathrm{Mn}^{\mathrm{III}}$ ions of metalloporphyrins in the polymeric chains, we further examine
Fig. 5 ORTEP view of crystal structure (top) and packing (bottom) of 5. Thermal ellipsoids (top) are drawn at the $50 \%$ probability level. Hydrogen atoms are omitted for clarity.

the X-ray structure. The average $\mathrm{Mn}^{\mathrm{III}}-\mathrm{N}_{\text {pyrrole }}$ distances of 2.011(3) $\AA$ for 4 and 2.013(3) $\AA$ for 5, respectively, and the remaining bond distances and angles fall into a typical range for manganese(III) porphyrins. ${ }^{11,13,25,26}$ No significant difference is expected in the $\mathrm{Mn}^{\mathrm{III}}-\mathrm{N}_{\text {pyrrole }}$ bond distances since the $\mathrm{d}_{x^{2}-y^{2}}$ orbital is formally unoccupied in both high- and low-spin states. The $\mathrm{Mn}^{\text {III- }}-\mathrm{N}_{\text {pyridine }}$ distances in both polymers $\mathbf{4}$ and $\mathbf{5}$ are about $0.1 \AA$ shorter than that of Cl(py)MnTPP (2.444(4) $\AA$ ), ${ }^{25}$ most likely the $\mathrm{Mn}^{\mathrm{III}}$ ions in the polymeric chains are in a low-spin state. 


\section{Magnetic properties}

The cryomagnetic properties of complexes $\mathbf{4}$ and $\mathbf{5}$ have been studied in the temperature range 5-300 K, with an applied field of 10000 gauss. As an example, the plots of $\mu_{\text {eff }}$ versus $T$, and $\chi_{\mathrm{M}}$ versus $T$ are shown in Fig. 6 , where $\chi_{\mathrm{M}}$ is the molar magnetic susceptibility per $\left[\mathrm{Ni}_{3}(\mathrm{dpa})_{4}(\mathrm{PyCOO})_{2}\right][\mathrm{MnTPP}]^{+}$ unit. The magnetic behavior observed for polymer 5 can be understood by considering the results of the X-ray structure analysis. The $\mathrm{Mn}^{\mathrm{III}}$ ions of $\mathrm{MnTPP}^{+}$unit is low-spin. It has been shown that the two terminal $\mathrm{Ni}^{\mathrm{II}}$ ions of linear trinickel complexes are high-spin. The room temperature effective magnetic moment is $5.28 \mu_{\mathrm{B}}$, which is consistent with noninteracting spins of two $S=1\left(\left[\mathrm{Ni}_{3}(\mathrm{dpa})_{4}(3-\mathrm{PyCOO})_{2}\right]\right.$ unit $)$ and $S=1$ $\left([\mathrm{MnTPP}]^{+}\right.$unit). The effective magnetic moment of complex $\mathbf{5}$ decreases gradually with lowering temperature from 300 to 75 $\mathrm{K}\left(4.85 \mu_{\mathrm{B}}\right)$, and then increases slowly, reaches a maximum of $5.23 \mu_{\mathrm{B}}$ at $10 \mathrm{~K}$. The magnetic behavior at low temperature suggest weak ferromagnetic interactions between $\mathrm{Mn}^{\mathrm{III}}$ and $\mathrm{Ni}^{\mathrm{II}}$ ions. Similar magnetic behavior for complex 4 with an effective magnetic moment of $4.97 \mu_{\mathrm{B}}$ at $300 \mathrm{~K}$ is also observed.

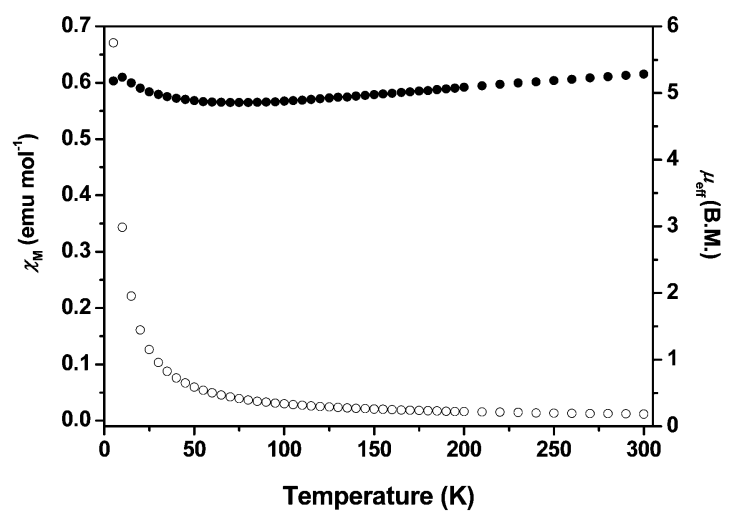

Fig. 6 Temperature-dependent magnetic effective moment (O) and molar magnetic susceptibility $(\bigcirc)$ for complex 5.

\section{Electronic absorption spectra}

The electronic properties of complex 3 has been studied in $\mathrm{CH}_{2} \mathrm{Cl}_{2}$ at room temperature. A comparison of the $\mathrm{UV} / \mathrm{vis}$ spectra of complexes 1, 3 and ZnTPP is shown in Fig. 7. The bands at 249, 313 and $340 \mathrm{~nm}$ in $\mathbf{3}$ are ascribed to complex $\mathbf{1}$, whereas the bands at 420 and $548 \mathrm{~nm}$ are correspond to ZnTPP chromopohore. The UV/vis spectra of complex $\mathbf{3}$ are essentially the sum of those of complex 1 and ZnTPP. This observation clearly provides evidence for the absence of any interactions

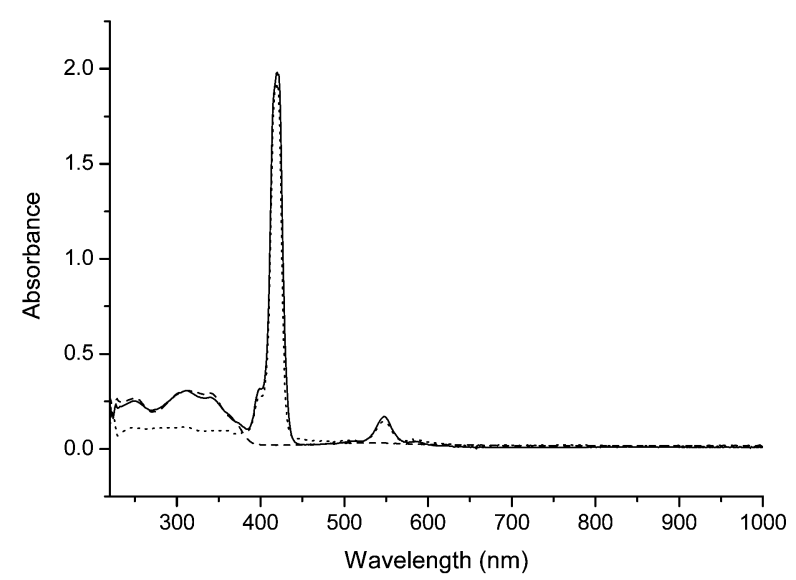

Fig. $7 \mathrm{UV} / v i$ absorption spectra of oligomer 3 (solid line), complex $\mathbf{1}$ (dashed line), and ZnTPP (dotted line) in $\mathrm{CH}_{2} \mathrm{Cl}_{2}$ at room temperature. Concentration: $5.0 \times 10^{-6} \mathrm{M}$. between the linear trinickel complexes and metalloporphyrins in these arrays.

The UV/vis spectra of complexes $\mathbf{4}$ and $\mathbf{5}$ are similar with each other. As an example, a comparison of the UV/vis spectra of complexes 1, $\mathbf{5}$ and [MnTPP] $\left(\mathrm{ClO}_{4}\right)$ are shown in Fig. 8. Polymer 5 shows absorption bands at 220, 340, 370, 472, 576 and $610 \mathrm{~nm}$, which are very similar to the combination of those of complex 1 and MnTPP ${ }^{+}$.

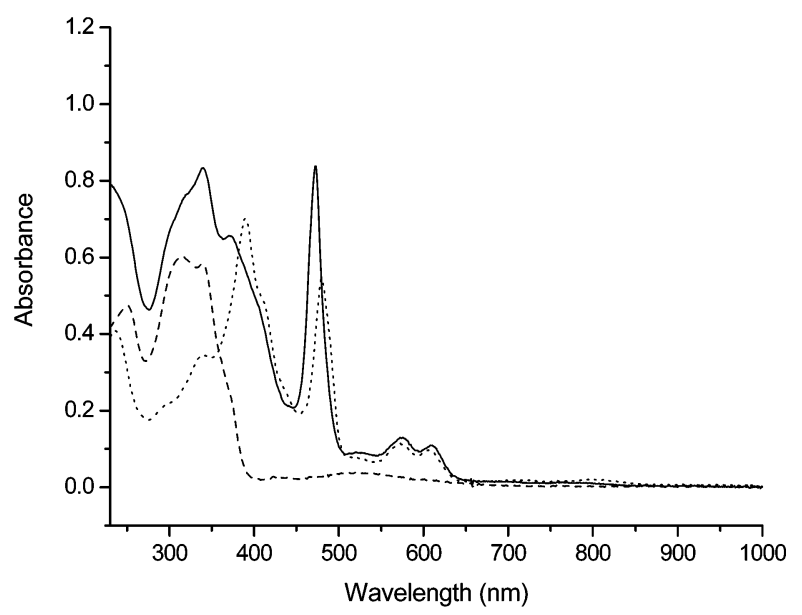

Fig. $8 \mathrm{UV} /$ vis absorption spectra of polymer $\mathbf{5}$ (solid line), complex 1 (dashed line), and $[\mathrm{MnTPP}]\left(\mathrm{ClO}_{4}\right)$ (dotted line) in $\mathrm{CH}_{2} \mathrm{Cl}_{2}$ at room temperature. Concentration: $1.0 \times 10^{-5} \mathrm{M}$.

\section{Conclusion}

A series of novel one-dimensional polymers and supramolecules comprised of linear trinickel complexes and metalloporphyrins are generated by self-assembly. Polymers $\mathbf{4}$ and $\mathbf{5}$ are a first example of magnetically ordered molecular material containing linear trinickel complexes and metalloporphyrins in the polymeric chains. The magnetic and UV/vis spectroscopic results indicate that the $\left[\mathrm{Ni}_{3}(\mathrm{dpa})_{4}(\mathrm{PyCOO})_{2}\right]$ units and metalloporphyrins are electronically noncommunicating. To increase the electronic coupling between the building blocks within the polymeric chains, it is necessary to use conjugated bidentate ligands such as acetylide to the bridge or trinuclear metal string with metal-metal bonds. Work along this line is currently underway in our laboratory.

\section{Experimental}

\section{Physical measurements}

Absorption spectra were measured in $\mathrm{CH}_{2} \mathrm{Cl}_{2}$ at room temperature with a Hewlett Packard 8453 spectrophotometer. IR spectra were recorded with a Nicolet Fourier-Transform IR spectrometer using $\mathrm{KBr}$ pellets as IR matrix. Elemental $(\mathrm{C}, \mathrm{H}, \mathrm{N})$ analyses were carried out on a Perkin-Elmer $\mathrm{CHN}$ 2400. FAB-MS mass spectra were obtained with a JEOL HX-110 HF double focusing spectrometer operating in the positive ion detection mode. Molar magnetic susceptibility was recorded in the range of 5-300 $\mathrm{K}$ on a SQUID system with a 10000 gauss external magnetic field.

\section{Materials}

The $\mathrm{ZnTPP}$ and [MnTPP] $\left(\mathrm{ClO}_{4}\right)$ were synthesized according to reported in the literature. ${ }^{20,21}$ The nicotinic acid and isonicotinic acid were purchased from Fluka Chemical Co., and the tetramethylammonium hydrate (25\% in methanol) was from Acros Chemical Co. $\mathrm{CH}_{2} \mathrm{Cl}_{2}$ was dried over $\mathrm{CaH}_{2}$ and distilled prior to use. All other chemicals are commercially available and were used as supplied. 


\section{Preparation of complexes}

[ $\mathrm{Ni}_{3}$ (dpa) $\mathbf{4}_{4} \mathbf{C l}_{2}$ ]. Hdpa (1.71 g, $\left.10 \mathrm{mmol}\right), \mathrm{NiCl}_{2}(0.972 \mathrm{~g}, 7.5$ $\mathrm{mmol})$ and naphthalene $(20 \mathrm{~g})$ were placed in an Erlenmejer flask. After stirring the mixture at $160{ }^{\circ} \mathrm{C}$ for $3 \mathrm{~h}, t$-BuOK $(1.12$ $\mathrm{g}, 10 \mathrm{mmol}$ ) in $t$-butanol was added. The temperature was increased and was slowly evaporated over a period of $30 \mathrm{~min}$. After cooling the mixture to $80^{\circ} \mathrm{C}$, hexane $(100 \mathrm{~mL})$ was added and the precipitate was filtered out. The solid was extracted with $\mathrm{CH}_{2} \mathrm{Cl}_{2}$ and recrystallized from $\mathrm{CH}_{2} \mathrm{Cl}_{2}$ and hexane. Crystallization from $\mathrm{CH}_{2} \mathrm{Cl}_{2}$ and hexane afforded purple-black crystals. Crystal yield: $2.20 \mathrm{~g}, 95 \%$. IR (KBr) $v / \mathrm{cm}^{-1}: 1599$ (s), 1553 (s), 1468 (vs), 1429 (vs), 1360 (vs); FAB/MS m/z: 926.3 $\left(\left[\mathrm{Ni}_{3}(\mathrm{dpa})_{4} \mathrm{Cl}_{2}\right]^{+}\right), 891.3\left(\left[\mathrm{Ni}_{3}(\mathrm{dpa})_{4} \mathrm{Cl}\right]^{+}\right), 856.3\left(\left[\mathrm{Ni}_{3}(\mathrm{dpa})_{4}\right]^{+}\right)$.

$\left[\mathrm{Ni}_{3}(\mathbf{d p a})_{4}(4-\mathrm{PyCOO})_{2}\right], \mathbf{1} . \mathrm{AgSO}_{3} \mathrm{CF}_{3}(514 \mathrm{mg}, 2.0 \mathrm{mmol})$ was added to a solution of $\left[\mathrm{Ni}_{3}(\mathrm{dpa})_{4} \mathrm{Cl}_{2}\right](926 \mathrm{mg}, 1.0 \mathrm{mmol})$ in $\mathrm{CH}_{2} \mathrm{Cl}_{2}(25 \mathrm{~mL})$ at room temperature. The resulting mixture was stirred for $30 \mathrm{~min}$ and then filtered. $\mathrm{A} \mathrm{CH}_{3} \mathrm{OH}$ solution $(10 \mathrm{~mL})$ of 4-PyCOO${ }^{-}\left(\mathrm{CH}_{3}\right)_{4} \mathrm{~N}^{+}$, which was prepared in situ from nicotinic acid $(264 \mathrm{mg}, 2.0 \mathrm{mmol})$ and $\left(\mathrm{CH}_{3}\right)_{4} \mathrm{NOH}(0.81$ $\mathrm{ml}, 2.0 \mathrm{mmol}$ ), was added to the filtrate. After stirring for $30 \mathrm{~min}$, the mixture was filtered. The solvent was removed via rotary evaporation to afford the desired product. Dark purple crystals were obtained from crystallization by slow diffusion of diethyl ether vapor into the solution of product in $\mathrm{CH}_{2} \mathrm{Cl}_{2}$. Crystal yield: $610 \mathrm{mg}, 55 \%$. IR (KBr) $v / \mathrm{cm}^{-1}: 1630$ (s), 1599 (s), 1553 (s), 1468 (vs), 1429 (vs), 1360 (vs); UV/vis $\left(\mathrm{CH}_{2} \mathrm{Cl}_{2}\right) \lambda_{\max }$ I $\mathrm{nm}\left(\varepsilon / \mathrm{dm}^{3} \mathrm{~mol}^{-1} \mathrm{~cm}^{-1}\right): 250\left(4.75 \times 10^{4}\right), 315\left(6.02 \times 10^{4}\right), 339$ $\left(5.84 \times 10^{4}\right), 518\left(3.7 \times 10^{3}\right.$ shoulder $) ; \mathrm{FAB} / \mathrm{MS} \mathrm{m} / \mathrm{z}: 1100.3$ $\left(\left[\mathrm{Ni}_{3}(\mathrm{dpa})_{4}(4-\mathrm{PyCOO})_{2}\right]^{+}\right), \quad 978.3 \quad\left(\left[\mathrm{Ni}_{3}(\mathrm{dpa})_{4}(4-\mathrm{PyCOO})\right]^{+}\right)$, $856.3\left(\left[\mathrm{Ni}_{3}(\mathrm{dpa})_{4}\right]^{+}\right)$. Anal. Calc. for $\mathrm{C}_{52} \mathrm{H}_{40} \mathrm{~N}_{14} \mathrm{Ni}_{3} \mathrm{O}_{4}$ : C 56.73, H 3.66, N 17.81; found: C 56.33, H 3.82, N 17.66.

[ $\left.\mathrm{Ni}_{3}(\mathrm{dpa})_{4}(\mathbf{3}-\mathrm{PyCOO})_{2}\right], 2$. Complex 2 was synthesized using a procedure similar to that for $\mathbf{1}$ except that isonicotinic acid instead of nicotinic acid was used. Dark purple crystals were obtained from crystallization by slow diffusion of diethyl ether vapor into the solution of product in $\mathrm{CH}_{2} \mathrm{Cl}_{2}$. Crystal yield: $615 \mathrm{mg}, 56 \%$. IR (KBr) $v / \mathrm{cm}^{-1}: 1630$ (s), 1599 (s), 1553 (s), 1468 (vs), 1429 (vs), 1360 (vs); UV/vis $\left(\mathrm{CH}_{2} \mathrm{Cl}_{2}\right) \lambda_{\max } / \mathrm{nm}\left(\varepsilon / \mathrm{dm}^{3}\right.$ $\left.\mathrm{mol}^{-1} \mathrm{~cm}^{-1}\right): 250\left(4.75 \times 10^{4}\right), 315\left(6.02 \times 10^{4}\right), 339\left(5.84 \times 10^{4}\right)$, $518\left(3.7 \times 10^{3}\right.$ shoulder $) ; \mathrm{FAB} / \mathrm{MS} \mathrm{m} / \mathrm{z}: 1100.3\left(\left[\mathrm{Ni}_{3}(\mathrm{dpa})_{4^{-}}\right.\right.$ $\left.\left.(3-\mathrm{PyCOO})_{2}\right]^{+}\right), 978.3\left(\left[\mathrm{Ni}_{3}(\mathrm{dpa})_{4}(3-\mathrm{PyCOO})\right]^{+}\right), 856.3\left(\left[\mathrm{Ni}_{3}-\right.\right.$ $\left.(\mathrm{dpa})_{4}\right]^{+}$). Anal. Calc. for $\mathrm{C}_{52} \mathrm{H}_{40} \mathrm{~N}_{14} \mathrm{Ni}_{3} \mathrm{O}_{4}$ : C 56.73, H 3.66, N 17.81; found: C 56.46, H 3.86, N 17.63.

$\left[\mathrm{Ni}_{3}(\mathrm{dpa})_{4}(4-\mathrm{PyCOO})_{2}\right][\mathrm{ZnTPP}]_{2}$, 3. $\left[\mathrm{Ni}_{3}(\mathrm{dpa})_{4}(4-\mathrm{PyCOO})_{2}\right]$ $(22 \mathrm{mg}, 0.02 \mathrm{mmol})$ and ZnTPP $(27 \mathrm{mg}, 0.04 \mathrm{mmol})$ were dissolved in $\mathrm{CH}_{2} \mathrm{Cl}_{2}(25 \mathrm{~mL})$ at room temperature. After stirring $5 \mathrm{~min}$, the solution became bright purple. Bright purple crystals were obtained from crystallization by slow diffusion of diethyl ether vapor into the solution of product in $\mathrm{CH}_{2} \mathrm{Cl}_{2}$. Crystal yield: $12 \mathrm{mg}, 24 \%$. IR (KBr) $v / \mathrm{cm}^{-1}: 1630$ (s), 1599 (s), 1553 (s), 1468 (vs), 1429 (vs), 1360 (vs); UV/vis $\left(\mathrm{CH}_{2} \mathrm{Cl}_{2}\right)$ $\lambda_{\text {max }} / \mathrm{nm}\left(\varepsilon / \mathrm{dm}^{3} \mathrm{~mol}^{-1} \mathrm{~cm}^{-1}\right): 249\left(5.05 \times 10^{4}\right), 313\left(6.12 \times 10^{4}\right)$, $340\left(5.43 \times 10^{4}\right), 420\left(3.96 \times 10^{5}\right), 548\left(3.40 \times 10^{4}\right) ; \mathrm{FAB} / \mathrm{MS}$ $m / z: 1779.5\left(\left[\mathrm{Ni}_{3}(\mathrm{dpa})_{4}(3-\mathrm{PyCOO})_{2}\right][\mathrm{ZnTPP}]^{+}\right), 1101.5\left(\left[\mathrm{Ni}_{3}{ }^{-}\right.\right.$ $\left.\left.(\mathrm{dpa})_{4}(4-\mathrm{PyCOO})_{2}\right]^{+}\right), \quad 978.4\left(\left[\mathrm{Ni}_{3}(\mathrm{dpa})_{4}(4-\mathrm{PyCOO})\right]^{+}\right), 676.3$ $\left([\mathrm{ZnTPP}]^{+}\right)$. Anal. Calc. for $\mathrm{C}_{140} \mathrm{H}_{96} \mathrm{~N}_{22} \mathrm{Ni}_{3} \mathrm{O}_{4} \mathrm{Zn}_{2}$ : C 68.43, $\mathrm{H}$ 3.94, N 12.54; found: C 68.51, H 3.99, N 12.60.

$\left\{\left[\mathrm{Ni}_{3}(\mathrm{dpa})_{4}(4-\mathrm{PyCOO})_{2}\right][\mathrm{MnTPP}]\right\}_{n}\left(\mathrm{ClO}_{4}\right)_{n}$, 4. Stoichiometric amounts of $\left[\mathrm{Ni}_{3}(\mathrm{dpa})_{4}(4-\mathrm{PyCOO})_{2}\right](55 \mathrm{mg}, 0.05 \mathrm{mmol})$ and $\mathrm{MnTPP} \mathrm{ClO}_{4}(38.5 \mathrm{mg}, 0.05 \mathrm{mmol})$ were dissolved in $\mathrm{CH}_{2} \mathrm{Cl}_{2}(25 \mathrm{~mL})$ at room temperature. After stirring for $5 \mathrm{~min}$, the solution turned from purple-black to dark brown. Dark brown crystals were obtained from crystallization by slow diffusion of diethyl ether vapor into the solution of product in $\mathrm{CH}_{2} \mathrm{Cl}_{2} / \mathrm{CH}_{3} \mathrm{OH}$ (v/v: 1 : 1). Crystal yield: $40 \mathrm{mg}, 43 \%$. IR
(KBr) $v / \mathrm{cm}^{-1}: 1630$ (s), 1599 (s), 1553 (s), 1468 (vs), 1429 (vs), 1360 (vs); UV/vis $\left(\mathrm{CH}_{2} \mathrm{Cl}_{2}\right) \quad \lambda_{\max } / \mathrm{nm}\left(\varepsilon / \mathrm{dm}^{3} \mathrm{~mol}^{-1} \quad \mathrm{~cm}^{-1}\right)$ : $220\left(1.44 \times 10^{5}\right), 340\left(8.35 \times 10^{4}\right), 370\left(6.51 \times 10^{4}\right), 472$ $\left(8.38 \times 10^{4}\right), 575\left(1.29 \times 10^{4}\right), 610\left(1.07 \times 10^{4}\right) ; \mathrm{FAB} / \mathrm{MS}$ $m / z: 1768.1\left(\left[\mathrm{Ni}_{3}(\mathrm{dpa})_{4}(4-\mathrm{PyCOO})_{2}\right]\left[\mathrm{MnTPP}^{+}\right), 1101.2\left(\left[\mathrm{Ni}_{3}-\right.\right.\right.$ $\left.\left.(\mathrm{dpa})_{4}(4-\mathrm{PyCOO})_{2}\right]^{+}\right), \quad 978.2\left(\left[\mathrm{Ni}_{3}(\mathrm{dpa})_{4}(4-\mathrm{PyCOO})\right]^{+}\right), 667.3$ $\left([\mathrm{MnTPP}]^{+}\right)$. Anal. Calc. for $\mathrm{C}_{96} \mathrm{H}_{68} \mathrm{ClMnN}_{18} \mathrm{Ni}_{3} \mathrm{O}_{8}: \mathrm{C} 61.72, \mathrm{H}$ 3.67, N 13.50; found: C 60.90, H 3.87, N 13.72.

$\left\{\left[\mathrm{Ni}_{3}(\mathrm{dpa})_{4}(3-\mathrm{PyCOO})_{2}\right][\mathrm{MnTPP}]\right\}_{n}\left(\mathrm{ClO}_{4}\right)_{n}$, 5. A procedure similar to that for complex $\mathbf{5}$ was employed except that $\left[\mathrm{Ni}_{3}(\mathrm{dpa})_{4}(3-\mathrm{PyCOO})_{2}\right]$ instead of $\left[\mathrm{Ni}_{3}(\mathrm{dpa})_{4}(4-\mathrm{PyCOO})_{2}\right]$ was used. Dark brown crystals were obtained from crystallization by slow diffusion of diethyl ether vapor into the solution of product in $\mathrm{CHCl}_{3}$. Crystal yield: $62 \mathrm{mg}, 66 \%$. IR $(\mathrm{KBr}) v / \mathrm{cm}^{-1}$ : 1630 (s), 1599 (s), 1553 (s), 1468 (vs), 1429 (vs), 1360 (vs); $\mathrm{UV} / \mathrm{vis}\left(\mathrm{CH}_{2} \mathrm{Cl}_{2}\right) \lambda_{\max } / \mathrm{nm}\left(\varepsilon / \mathrm{dm}^{3} \mathrm{~mol}^{-1} \mathrm{~cm}^{-1}\right): 220\left(1.45 \times 10^{5}\right)$, $340\left(8.33 \times 10^{4}\right), 370\left(6.56 \times 10^{4}\right), 472\left(8.38 \times 10^{4}\right), 576(1.29 \times$ $\left.10^{4}\right), 610\left(1.09 \times 10^{4}\right) ; \mathrm{FAB} / \mathrm{MS} \mathrm{m} / \mathrm{z}: 1768.1\left(\left[\mathrm{Ni}_{3}(\mathrm{dpa})_{4}{ }^{-}\right.\right.$ $\left.\left.(3-\mathrm{PyCOO})_{2}\right][\mathrm{MnTPP}]^{+}\right), \quad 1100.3 \quad\left(\left[\mathrm{Ni}_{3}(\mathrm{dpa})_{4}(3-\mathrm{PyCOO})_{2}\right]^{+}\right)$, $978.3\left(\left[\mathrm{Ni}_{3}(\mathrm{dpa})_{4}(3-\mathrm{PyCOO})\right]^{+}\right), 667.3\left([\mathrm{MnTPP}]^{+}\right)$. Anal. Calc. for $\mathrm{C}_{96} \mathrm{H}_{68} \mathrm{ClMnN}_{18} \mathrm{Ni}_{3} \mathrm{O}_{8}$ : C 61.72, $\mathrm{H}$ 3.67, N 13.50; found: C 61.89, H 3.77, N 13.71.

\section{Crystal structure determinations}

Crystallographic information for $\mathbf{1}-\mathbf{5}$ is summarized in Table 3. The chosen crystals were mounted on a glass fiber. X-ray diffraction data for $\mathbf{1 - 5}$ were collected at $150 \mathrm{~K}$ on a NONIUS Kappa CCD diffractometer installed with monochromatized Mo K $\alpha$ radiation, $\lambda=0.71073 \AA$ A Cell parameters were retrieved and refined using DENZO-SMN software on all observed reflections. ${ }^{27}$ Data reduction was performed with the $D E N Z O$ $S M N$ software. ${ }^{27}$ An empirical absorption was based on the symmetry-equivalent reflections and absorption corrections were applied with the SORTAV program.$^{28}$ All the structures were solved by using the SHELXS-97 ${ }^{29}$ and refined with SHELXL- $97^{30}$ by full-matrix least squares on $F^{2}$ values. Hydrogen atoms were fixed at calculated positions and refined using a riding mode.

CCDC reference numbers 199616-199620.

See http://www.rsc.org/suppdata/dt/b2/b212236g/ for crystallographic data in CIF or other electronic format.

\section{Acknowledgement}

The authors acknowledge the National Science Council and Ministry of Education of Taiwan for financial support.

\section{References}

1 S. Aduldecha and B. Hathaway, J. Chem. Soc., Dalton. Trans., 1991, 993.

2 G. J. Pyrka, M. El-Mekki and A. A. Pinkerton, J. Chem. Soc., Chem. Commun., 1991, 84; L.-P. Wu, P. Field, T. Morrissey, C. Murphy, P. Nagle, B. Hathaway, C. Simmons and P. Thornton, J. Chem. Soc., Dalton. Trans., 1990, 3835

3 D. W. Bruce and D. O'Hare, Inorganic Materials, Wiley, 1992; J. S. Miller, Extended Linear Chain Compounds, Plenum, New York, 1982, vol. 1-3; L. Oriol and J. L. Serrano, Adv. Mater., 1995, 7, 348; N. G. Connelly and W. E. Geiger, Adv. Organomet. Chem., 1984, 23, 1; N. G. Connelly and W. E. Geiger, Adv. Organomet. Chem., 1985, 24, 87.

4 F. A. Cotton and R. A. Walton, Multiple Bonds Between Metal Atoms, Clarendon Press, Oxford, 2nd edn., 1993.

5 F. A. Cotton and T. R. Felthouse, Inorg. Chem., 1981, 20, 600; F. D. Cukiernik, A.-M. Giroud-Godquin, P. Maldivi and J.-C. Marchon, Inorg. Chim. Acta, 1994, 215, 203; F. A. Cotton and T. R. Felthouse, Inorg. Chem., 1980, 19, 328; B. Morison, R. C. Hughes and Z. G. Soos, Acta Crystallogr., Sect. B, 1975, B31, 762.

6 M. Handa, K. Kasamatsu, K. Kasuge, M. Mikuriya and T. Fujii, Chem. Lett., 1990, 1753; M. Handa, H. Matsumoto, D. Yashioka, R. Nukada, M. Mikuriya, I. Hiromitsu and K. Kasuge, Bull. Chem. 
Soc. Jpn., 1998, 71, 1811; X. Ouyang, C. Campana and K. R. Dunbar, Inorg. Chem., 1996, 35, 7188; M. C. Kerby, B. W. Eichhorn, J. A. Creighton and K. P. C. Vollhardt, Inorg. Chem., 1990, 29, 1319 W.-M. Xue, F. E. Kühn, E. Herdtweck and Q. Li, Eur. J. Inorg. Chem., 2001, 213.

7 M. J. Bennett, K. G. Caulton and F. A. Cotton, Inorg. Chem., 1969 8, 1; B. K. Das and A. R. Chakravarty, Polyhedron, 1991, 10, 491; M. McCann, A. Carvill, P. Guinan, P. Higgings, J. Campbell, H. Ryan, M. Walsh, G. Ferguson and J. Gallagher, Polyhedron, 1991, 10, 2271; A. Bino, F. A. Cotton and T. R. Felthouse, Inorg. Chem., 1979, 18, 2599; T. Togano, M. Mukaida and T. Nomura, Bull. Chem. Soc. Jpn., 1980, 53, 2085; D. S. Martin, R. A. Newman and L. M. Vlasnik, Inorg. Chem., 1980, 19, 3404; F. A. Cotton, Y. Kim and T. Ren, Polyhedron, 1993, 12, 607; F. D. Cukiemik, D. Luneau, J. C. Marchon and P. Maldivi, Inorg. Chem., 1998, 37, 3698; M. C. Barral, R. Jiménez-Aparicio, D. Pérez-Quintanilla, E. Pinilla, J. L. Priego, E. C. Royer and F. A. Urbanos, Polyhedron, 1998, 18, 371.

8 F. A. Cotton, T. Kim and T. Ren, Inorg. Chem., 1992, 31, 2723; J. Telser and R. S. Drago, Inorg. Chem., 1984, 23, 3114; M. Handa, Y. Sayama, M. Mikuriya, R. Nukada, I. Hiromitsu and K. Kasuge, Bull. Chem. Soc. Jpn., 1995, 68, 1647; M. Handa, Y. Sayama M. Mikuriya, R. Nukada, I. Hiromitsu and K. Kasuge, Chem. Lett., 1996, 201; Y. Sayama, M. Handa, M. Mikuriya, I. Hiromitsu and K. Kasuge, Chem. Lett., 1998, 777; H. Miyasaka, R. Clérac, C. S. Campos-Fernández and K. R. Dunbar, Inorg. Chem., 2001, 40, 1663.

9 C.-H. Peng, C.-C. Wang, H.-C. Lee, W.-C. Lo, G.-H. Lee and S.-M. Peng, J. Chin. Chem. Soc., 2001, 48, 987.

10 H. Nishide, H. Kawakami, T. Suzuki, Y. Azechi, Y. Soejima and E. Tsuchida, Macromolecules, 1991, 24, 6306; H. L. Anderson and J. K. M. Sanders, Angew. Chem., Int. Ed. Engl., 1991, 29, 1400.

11 J. S. Miller, J. C. Calabrese, R. S. McLean and A. J. Epstein, Adv. Mater., 1992, 4, 498.

12 S. Anderson, H. L. Anderson and J. K. M. Sanders, Acc. Chem. Res., 1993, 26, 469

13 J. T. Landrum, C. A. Reed, K. Hatano and W. R. Scheidt, J. Am. Chem. Soc., 1978, 100, 3232; J. T. Landrum, K. Hatano, W. R. Scheidt and C. A. Reed, J. Am. Chem. Soc., 1980, 102, 6729.

14 A. H. White, B. W. Skelton, T. W. Hambley, M. J. Gunter and P. Turner, Inorg. Chem., 1992, 31, 2297.

15 E. J. Brandon, R. D. Rogers, B. M. Burkhart and J. S. Miller, Chem. Eur. J., 1998, 4, 1938 .
16 R. K. Kumar, S. Balasubramanian and I. Goldberg, Chem. Commun., 1998, 1435.

17 Y. Diskin-Posner, G. Kumar Patra and I. Goldberg, J. Chem. Soc., Dalton Trans., 2001, 2775; R. Krishna Kumar and I. Goldberg, Angew. Chem., Int. Ed., 1998, 37, 3027.

18 Y. Diskin-Posner, S. Dahal and I. Goldberg, Angew. Chem., Int. Ed., 2000, 39, 1288

19 A. D. Shukla, P. C. Dave, E. Suresh, A. Das and P. Dastidar, J. Chem. Soc., Dalton Trans., 2000, 4459.

20 A. D. Adler, F. R. Longo, J. D. Finarelli, J. Goldmacher, J. Assour and L. Korsakoff, J. Org. Chem., 1967, 32, 476.

21 A. D. Adler, F. R. Longo, F. Kampas and J. Kim, J. Inorg. Nucl. Chem., 1970, 32, 2443.

22 S.-J. Shieh, C.-C. Chou, G.-H. Lee, C.-C. Wang and S.-M. Peng, Angew. Chem., Int. Ed. Engl., 1997, 36, 56; C.-C. Wang, W.-C. Lo, C.-C. Chou, G.-H. Lee, J.-M. Chen and S.-M. Peng, Inorg. Chem., 1998, 37, 4059 .

23 S.-Y. Lai, T.-W. Lin, Y.-H. Chen, C.-C. Wang, G.-H. Lee, M.-H. Yang, M.-K. Leung and S.-M. Peng, J. Am. Chem. Soc., 1999, 121, 250; S.-Y. Lai, C.-C. Wang, Y.-H. Chen, C.-C. Lee, Y.-H. Liu and S.-M. Peng, J. Chin. Chem. Soc., 1999, 46, 477.

24 S.-M. Peng, C.-C. Wang, Y.-L. Jang, Y.-H. Chen, F.-Y. Li C.-Y. Mou and M.-K. Leung, J. Magn. Magn. Mater, 2000, 209, 80.

25 J. F. Kirner and W. R. Scheidt, Inorg. Chem., 1975, 14, 2081.

26 A. Böhm, C. Vazquez, R. S. McLean, J. C. Calabrese, S. E. Kalm, J. L. Manson, A. J. Epstein and J. S. Miller, Inorg. Chem., 1996, 35, 3083; E. J. Brandon, D. K. Rittenberg, A. M. Arif and J. S. Miller, Inorg. Chem., 1998, 37, 3376; J. T. Landrum, K. Hatano, W. R. Scheidt and C. A. Reed, J. Am. Chem. Soc., 1980, 102, 6729; C. L. Hill and M. M. Williamson, Inorg. Chem., 1985, 24, 2834, 3024; E. B. Fleischer, Acc. Chem. Res., 1970, 3, 105; W. R. Scheidt and C. A. Reed, Chem. Rev., 1981, 81, 543; P. Turner, M. J. Gunter, T. W. Hambley, A. H. White and B. W. Skelton, Inorg. Chem., 1992, 31, 2297; K.-i. Sugiura, A. Arif, J. Schweizer, L. Öhrstrom, A. J. Epstein and J. S. Miller, Chem. Eur. J., 1997, 3, 138.

27 Z. Otwinowski and W. Minor, Processing of X-ray Diffraction Data Collected in Oscillation Mode, Methods in Enzymology, Volume 276: Macromolecular Crystallography, part A, ed. C. W. Carter and R. M. Sweet, Jr., Academic Press, 1997.

28 R. H. Blessing, Acta Crystallogr., Sect. A, 1995, A51, 33.

29 G. M. Sheldrick, Acta Crystallogr., Sect. A, 1990, A46, 467.

30 G. M. Sheldrick, SHELXL-97, Program for the Refinement of Crystal Structures, University of Göttingen, Germany, 1997. 